\title{
Sustainable, Decentralized Sanitation and Reuse with Hybrid Nature-Based Systems
}

\author{
Andrea G. Capodaglio*(D), Silvia Bolognesi $(\mathbb{D}$ and Daniele Cecconet \\ Department of Civil Engineering \& Architecture, University of Pavia, 27100 Pavia, Italy; \\ silvia.bolognesi@unipv.it (S.B.); daniele.cecconet@unipv.it (D.C.) \\ * Correspondence: capo@unipv.it
}

check for updates

Citation: Capodaglio, A.G.;

Bolognesi, S.; Cecconet, D.

Sustainable, Decentralized Sanitation and Reuse with Hybrid Nature-Based Systems. Water 2021, 13, 1583.

https://doi.org/10.3390/w13111583

Academic Editor: Alexandros

I. Stefanakis

Received: 30 April 2021

Accepted: 2 June 2021

Published: 3 June 2021

Publisher's Note: MDPI stays neutral with regard to jurisdictional claims in published maps and institutional affiliations.

Copyright: (c) 2021 by the authors. Licensee MDPI, Basel, Switzerland. This article is an open access article distributed under the terms and conditions of the Creative Commons Attribution (CC BY) license (https:// creativecommons.org/licenses/by/ $4.0 /)$

\begin{abstract}
Nature (ecosystem) based processes for wastewater treatment include constructed wetlands (CWs), waste stabilization ponds, vegetated drainage ditches, buffer zones, instream or bankside river techniques, and mixotrophic systems, where light and $\mathrm{CO}_{2}$ are utilized, in addition to organic carbon compounds, by algal cultures. Algae-based systems can simultaneously remove organic matter, $\mathrm{N}$, and $\mathrm{P}$ and may offer substantial energetic advantages compared to traditional biological treatment systems, require small spatial footprint, and contribute to biofuels production and $\mathrm{CO}_{2}$ emissions mitigation. Bioelectrochemical systems (BES) such as microbial fuel cells (MFCs) present characteristics compatible with the use in isolated realities for water and wastewater treatment with contextual energy recovery and may be combined with other nature-based process technologies to achieve good treatment and energy efficiencies. Despite that their application in real-scale plants has not been assessed yet, the most probable outcome will be the in situ/on site treatment (or pretreatment) of wastes for small "in house" plants not connected to the sewerage network. This paper focuses on the current practices and perspectives of hybrid nature-based systems, such as constructed wetlands and microalgae integrated phytoremediation plants, and their possible integration with microbial electrochemical technologies to increase recovery possibilities from wastes and positively contribute to a green economy approach.
\end{abstract}

Keywords: nature-based wastewater treatment systems; constructed wetlands; microalgae; microbial electrochemical systems; sustainable wastewater management

\section{Introduction}

About half of the world population still lives in rural areas. Even in the European Union (EU), about $30 \%$ of the population of Eastern countries (over 40 million people) lives in small settlements (less than 2000 inhabitants), just less than $20 \%$ in the Western part [1]. In many other countries a still preponderantly rural or peri-urban (defined as a community near a large urban area, but without related public services) settlement situation exists. Provision of proper sanitation systems, according to the United Nations Sustainable Development Goals (Goal 6, "Clean Water and Sanitation"), foresees access to adequate and equitable sanitation and hygiene for all, reduction by half of untreated wastewater discharges, and a substantial increase in water recycling and safe reuse by 2030. At the moment, over 2 billion people live in water-stressed areas, and globally more than $80 \%$ of wastewater from human activities is still discharged without any pollution removal [2]. Issues about energy implications of the water cycle [3], sustainability of water treatment technologies in different settings, and on new paradigms concerning provision of the most efficient and resilient supply and sanitation services according to local needs [4] are the subject of intense debate in the water sector community. Arguments in favor of decentralized wastewater management systems for communities in rural or peri-urban areas have been discussed and advocated by many [1,4-6].

While it has been pointed out that in remote, low-income, and water-scarce areas centralized water treatment and supply could result in unsustainable economic burdens 
for the served communities [7], decentralization could be the logical solution to address sustainability issues. Various types of current technologies, appropriately applied, can provide local water reuse possibilities for practically all uses, non-potable and potable, to overcome chronic or contingent water scarcity situations [8]. Life cycle assessment (LCA) analyses showed consistent disadvantages of prevailing centralized paradigm approaches under specific local conditions in water-scarce countries, with alternatives consisting of source-separated systems and local water reuse [9].

Since the last decade of the second millennium, the USEPA recognized that "decentralized wastewater systems may provide a cost-effective and long-term option for meeting public health and water quality goals, particularly in less densely populated areas" [10]. In 2012, the US National Research Council indicated wastewater reuse as a yet untapped available water source [11]. Various strategies to optimize flow segregation may be instrumental to its reuse and the recovery of embedded resources [12]. While the choice to decentralize implies new approaches to planning, decision making, design of infrastructure, and arrangements for systems operation, its implications are not limited to the provision of an otherwise complex-to-implement essential service, but also to the possible adoption of more efficient technologies for local resource recycle and recovery, and to enhance the resilience and sustainability of local ecosystems.

Nature (or ecosystem) based processes for wastewater treatment have been used for centuries and include constructed wetlands (CWs), waste stabilization ponds, vegetated drainage ditches, buffer zones, and instream or bankside river techniques. These are based on the natural capacity of microorganisms and plants to act in synergy for recreating processes developed in natural wetlands, exploiting complex biochemical, physical, and physiological pollutant removal processes.

Bioelectrochemical systems (BES) such as microbial fuel cells (MFCs) present characteristics compatible with the use in isolated realities for water and wastewater treatment with contextual energy recovery [13] and may be combined with other nature-based process technologies to achieve good treatment and energy efficiencies. Despite that their application in real-scale plants has not been assessed yet, the most probable outcome will be the in situ/on site treatment (or pretreatment) of wastes for small "in house" plants not connected to the sewerage network.

This paper focuses on the current practices and perspectives of hybrid nature-based systems, such as constructed wetlands and microalgae integrated phytoremediation plants, and their possible integration with microbial electrochemical technologies to increase recovery possibility from wastes and positively contribute to a green economy approach.

\section{Nature-Based Wastewater Treatment Systems}

Application of CWs for effluents treatment represents today a practical solution in many parts of the world as decentralized alternative to traditional systems. A diversity of configurations and operational features can be adapted to treat domestic, agricultural, and industrial (mostly agro-food) wastewaters. Use of CWs in recent years has increased sharply in Mediterranean countries due to favorable climatic conditions, and positive experiences have been reported even in colder countries [14]. CWs have several notable advantages compared to traditional systems, including low capital and operating costs, infrastructure and design simplicity, and ease of operation [15]. The large areal footprint and water evaporation in hot climates could constitute the main drawbacks of these systems, with land requirements starting from about $2 \mathrm{~m}^{2} /$ P.E. (population equivalent, i.e., the measure of the average pollutants' load generated in a day by one person, conventionally assumed as $54 \mathrm{~g}$ of $\mathrm{BOD}_{5}$ ) in warm climates to $12 \mathrm{~m}^{2} /$ P.E. in cold ones. CWs generally show good pollutant removal efficiency, strong adaptability to load changes, and ideal removal of ammonia nitrogen [16]. Nutrient removal is provided both by biological and physico-chemical processes and is normally dependent on seasonality [17].

CWs can be classified according to the prevailing type of macrophytes present in the system, such as floating (e.g., Lemna), submerged rooted (e.g., Elodea), emergent rooted 
(e.g., Phragmites, Typha), or a combination thereof. Emergent rooted systems can then be classified according to their hydraulic regime: free surface flow (FSF), horizontal subsurface flow (HSF), or vertical subsurface flow (VSF) [18]. Among these, HSF systems are the most widely used due to their design simplicity. They are mainly anaerobic in nature, but present redox variations within, with the upper part remaining aerobic due to its contact with the atmosphere [19].

CW pollutant removal processes are generally slow due to their prevailing anaerobic conditions; removal efficiency depends mostly on soil hydraulic conductivity, presence of macrophytes and microorganisms, redox conditions, type of substrate, and local climate. FSF systems are more sensitive to solar radiation and tend to be more effective in warmer climates.

Recent technical improvements in these systems have been introduced to improve performance and reduce costs, such as French Reed Bed CWs for raw wastewater, which avoid primary treatment, or aerated wetland systems, which decrease the necessary footprint in comparison to conventional solutions. In aerated wetlands, aerobic processes development is increased significantly due oxygen transfer rates up to 10 times higher than that in conventional HSF. Although this requires an additional energy input, the resulting footprint is reduced up to $75-80 \%$ compared to conventional CWs, and energy consumption remains at least 5 times lower compared to conventional activated sludge systems. These are indicated as "intensified constructed wetlands" [20].

In order to develop nature-based systems that combine the best operating concepts of existing technologies, multistage systems have been proposed to optimize the design function of CWs to different effluent water quality targets. Multiple-stage systems are becoming more common due to higher tolerance to variations in flow, load and waste characteristics, and generally lower footprint [21,22].

CWs offer reliable and steady removal of total suspended solids (TSS) and organic matter (in the long-term, over $97 \%$ ), and nutrients can be removed up to $70-86 \%$ (ammonia), or up to $60-70 \%$ (Total $\mathrm{N}$ ). On the other hand, $\mathrm{P}$ removal efficiency is relatively low, less than $50 \%$ of that for nitrogen. CW systems can be easily incorporated in the circular economy or water reuse schemes: vegetated biomass harvesting can be used for energy recovery purposes, or partial treatment can generate effluents still rich in nutrients well suited to irrigation of non-edible crops. Reported operating costs are quite low, about $0.1 € / \mathrm{m}^{3}$ treated wastewater, with construction costs related, for the most part, to land area [15].

One of the biggest challenges in extensive application of CW technology is related to low degradation kinetics, implying low applicable specific pollutant loads, and large areal extension of facilities. To accelerate their treatment performance, attempts have been made, addressing both system configuration and process condition improvements. Examples of proposed operational improvements include hydraulic (e.g., effluent recirculation, flow direction reciprocation, baffled subsurface-flow), biological (e.g., earthworm integration, bioaugmentation) and process modifications (e.g., artificial and drop aeration, redox conditions improvement) [23].

Recently, a new class of nature-based, mixotrophic systems, where light and $\mathrm{CO}_{2}$ are utilized in addition to the organic carbon compound by algal cultures, has been studied. Algae-based systems can simultaneously remove organic matter, N, and P [24,25] and may offer substantial energetic advantages compared to traditional biological treatment systems, require smaller spatial footprint than $\mathrm{CWs}$, and contribute to biofuel production and $\mathrm{CO}_{2}$ emission mitigation [26]. Microalgae applications in wastewater treatment were first studied in the 1950s, when the symbiotic relationship between microalgae and bacteria showed the capacity to protect algae from toxic compounds in wastewater, improving contaminants removal: microalgae use $\mathrm{CO}_{2}$ through photosynthesis, and the generated oxygen is used by heterotrophic bacteria to assimilate carbon and nutrients. $\mathrm{CO}_{2}$ and inorganic $\mathrm{N}$ and $\mathrm{P}$ released by aerobic bacterial metabolism are in turn used by microalgae, able to assimilate significant amounts of nutrients due to the high demand for protein, 
nucleic acids, and phospholipids. All this occurs at lower cost compared to conventional biological treatment facilities [27]. In addition to removal of contaminants, algal biomass produced during treatment could generate considerable additional value as feedstock in biorefineries or other applications [28,29]. The main types of algae-based systems currently implemented are the tubular photobioreactor type (closed systems consisting of a clear tube in which algae are circulated and gas exchange units adding $\mathrm{CO}_{2}$ and stripping photosynthetically produced oxygen); the stabilization pond type (very similar in concept to free horizontal pond wetlands); fully engineered facilities (usually free surface, carousel type units) similar to conventional biological plants with low energy input requirements comparable to CW systems [30]. Energy consumption in these systems is in fact much lower (at least tenfold) compared to conventional wastewater treatment plants, at around $0.02 \mathrm{kWh} / \mathrm{m}^{3}$ treated [3]. High-rate algal ponds are built as shallow raceway ponds, where treated water is mixed by paddle wheels, and are getting attention in Mediterranean regions due to suitable climatic conditions and high insolation. However, similarly to CWs, they require large land areas (around $6 \mathrm{~m}^{2} /$ P.E.) [31].

For the purpose of this discussion the latter types will therefore be considered a class of nature-based systems. Table 1 summarizes some reported examples of full-scale algae-based wastewater treatment applications and related removal rates.

Table 1. Microalgae removal for C, N, and P from municipal wastewater in full-scale facilities.

\begin{tabular}{|c|c|c|c|c|c|c|c|}
\hline Substrate Type & Reactor Type & Volume $\left[\mathrm{m}^{3}\right]$ & Flow $\left[\mathrm{m}^{3} / \mathrm{d}\right]$ & $\begin{array}{c}\text { Carbon } \\
\text { Removal [\%] }\end{array}$ & $\begin{array}{c}\text { N Removal } \\
{[\%]}\end{array}$ & $\begin{array}{c}\text { P Removal } \\
{[\%]}\end{array}$ & Ref. \\
\hline Primary treated & $\begin{array}{l}\text { High rate pond, } \\
\text { natural light }\end{array}$ & 4375 & 30,000 & n.d. & 79 & 22 & [32] \\
\hline UASB $^{*}$ effluent & $\begin{array}{l}\text { High rate pond, } \\
\text { natural light }\end{array}$ & 9600 & 67,000 & 64 & 94 & 58 & [33] \\
\hline $\begin{array}{l}\text { Digested effluent } \\
\text { from anaerobic } \\
\text { pond }\end{array}$ & $\begin{array}{l}\text { High rate pond, } \\
\text { natural light }+ \\
\text { maturation pond }\end{array}$ & 4996 & 23,000 & $\begin{array}{l}73 \\
65 \\
54\end{array}$ & $\begin{array}{c}39 \text { (winter) } \\
58 \text { (spring) } \\
85 \text { (summer) }\end{array}$ & $\begin{array}{c}13 \text { (winter) } \\
-4 \\
2\end{array}$ & [34] \\
\hline $\begin{array}{l}\text { Anaerobic pond, } \\
\text { treated domestic } \\
\text { wastewater }\end{array}$ & $\begin{array}{l}\text { High rate pond, } \\
\text { natural light }\end{array}$ & 1200 & 5000 & $32-45$ & $22-79$ & $30-53$ & [35] \\
\hline
\end{tabular}

Upflow Anaerobic Sludge Blanket reactor.

One of the major drawbacks for cost-effective wastewater processing with algae-based systems is biomass harvesting and downstream processing. Algae present a very small fraction (up to $0.05 \%$ ) of dry weigh in suspension, cell microscopic size, and negative cell surface charge. These factors prevent the biomass from agglomerating and forming easily harvestable particles, which may significantly increase the costs of biomass final separation. Centrifugation, dissolved air flotation or flocculation by electrolytes, and synthetic polymers may enhance biomass separation. It is estimated that cost of algae biomass harvesting can constitute up to $30 \%$ of total process expenses [36]. Algal pond systems, however, can become cost-effective alternatives to CWs and conventional systems when coupled with biorefinery or biofertilizer production from biomass, which offer higher added value of byproducts compared to the energy recovery obtained from its co-digestion [31].

\section{Can Technology Integration Improve Nature-Based Systems?}

Despite the many application examples and innovation attempts, performance limitations still remain in all types of CWs, particularly concerning poor $\mathrm{N}$ removal and oxygen availability. Manipulation of redox conditions in these systems has been investigated. The so-called intensified CWs include aeration strategies such as tidal flow, i.e., system operation in alternate flooded and dry conditions (similarly to sequencing batch reactors, SBRs) [37], effluent recirculation, and artificial aeration [38]. Other intensification methods tested to enhance nitrogen removal are addition of external carbon to increase 
denitrification [39] and use of reactive media (e.g., calcite, zeolite) for enhanced ammonium removal [40]. Still, all types of CWs demonstrate large variations of removal efficiencies concerning quality parameters [41].

Algae-based systems also show reduced biomass growth rates at lower temperatures and limited efficiency during short vegetation season and short daylight periods. Furthermore, algal bioremediation efficiency decreases with system size scale-up. Wastewater treatment and the resource recovery performance of algae-based processes in small communities may be improved by reducing ammonia volatilization via $\mathrm{pH}$ control with $\mathrm{CO}_{2}$ injection, implementing these systems in the most favorable geographical locations and improving design to decrease the amount of construction materials [42].

New approaches to improve wastewater treatment efficiency and reuse options have pushed attempts to integrate different emerging technologies into nature-based systems. These include the combination of bioelectrochemical systems (BESs) into constructed wetlands, or microalgae systems, which has shown opportunities to improve the performance of both by exploiting each other's inherent features.

\subsection{CW-BES Hybrid Systems}

BESs are a class of biologically mediated processes that have received much attention in recent years for wastewater treatment applications [43]. BESs have been studied in the treatment of domestic [44] and industrial [45] wastewater, denitrification of effluents [46], greywater [13], groundwater [47] and landfill leachate treatment [48], environmental remediation [49], and removal of metals and hazardous pollutants [50]. In general, BESs require the presence of a redox gradient between an anode-cathode dipole, to initiate biological conversion processes of organic substrates. Electrochemically active bacteria (EAB) in BESs exploit the energy gain from this redox gradient to act as catalysts, transferring electrons derived from oxidation of organic and inorganic compounds at the anode to the cathode, creating a current, or using this gradient to induce energetically unfavorable reactions. Microbial fuel cells (MFCs) directly convert the chemical energy of an organic bioconvertible substrate into electrical energy through the mediation of EAB acting as catalyzers of a spontaneous half-reaction of substrate oxidation [51], while microbial electrolysis cells (MECs) operate at different externally set potentials to induce organic and inorganic compound transformations [52]. Often, these systems are more energetically efficient than current conventional technologies [53]. BESs are a promising alternative to conventional technologies for treatment of a wide range of wastewaters, although full-scale applications are still rare due to the remaining technological and operating issues, such as suitable material costs and operating conditions [54], reactor hydrodynamics [55], and other factors limiting the theoretically expected energy recovery [56]. An attractive approach to improve the performance and attractiveness of MFCs is to integrate them with other technologies, for example to produce hydrogen or other value-added products. Although MFC hybrid systems are still at an early stage of development, they could overcome the known limitations of standalone MFC systems, reducing costs and increasing performance and productivity. Among the proposals that have been recently advanced are the combination of MFCs with electro-Fenton and photochemical processes, membrane bioreactors, electrolysis cells, and constructed wetlands [57].

CWs naturally exhibit a pronounced redox gradient within the filter bed, and this is especially evident in HSF systems. Biofilm accumulates in water-saturated soil media thanks to the presence of carbon sources (organics, $\mathrm{CO}_{2}$ ), nitrogen, macro- and micronutrients, electron acceptors $\left(\mathrm{O}_{2}, \mathrm{NO}_{3}{ }^{-}\right.$, etc. $)$and donors $\left(\mathrm{H}_{2}, \mathrm{H}_{2} \mathrm{~S}, \mathrm{Fe}^{2+}\right.$, etc. $)$, and could greatly enhance the characteristics of an electrochemical system, supporting higher current densities [58]. This behavior could be exploited in synergy with the above-described BESs with potential to improve contaminant removal and the possibility to allow treatment of a broader range of contaminants. The rationale behind this approach is to promote the naturally occurring reactions by providing additional electron acceptors (the anode 
electrode) in the anaerobic zone of a CW. In doing this, CW performance intensification and electricity generation can be simultaneously achieved [59].

CW-BES systems may thus enable wastewater treatment with contaminant removal by biological degradation and bioelectrochemical pathways either in active (MFC) or passive (MEC) mode. As a consequence of either setup, the specific surface area requirements of CWs could be reduced.

A CW-MFC system consists of an anode, located in the anaerobic zone, and a cathode located in the anoxic/aerobic zone. Anodic activity of electroactive bacteria consumes present organic matter, releasing electrons that travel to the cathode by means of an external circuit (put in place when the $\mathrm{CW}$ is constructed), where they are used in $\mathrm{O}_{2}$ (or another terminal electron acceptor, TEA, such as $\mathrm{NO}_{3}{ }^{-}$) reduction. Combined CW-MFC systems have been operated with many different species of aquatic plants, including Canna indica, Pennisetum setaceum, Cyperus involucratus, Typha latifolia, Acorus calamus, Echinochloa glabrescens, Phragmites australis, Ipomea aquatica, Lolium perenne, Echinorriea crassipes, Alocasia macrorrhiza, Typha angustifolia, and several others [60]. Figure 1 shows a schematic of BES integration in CW.

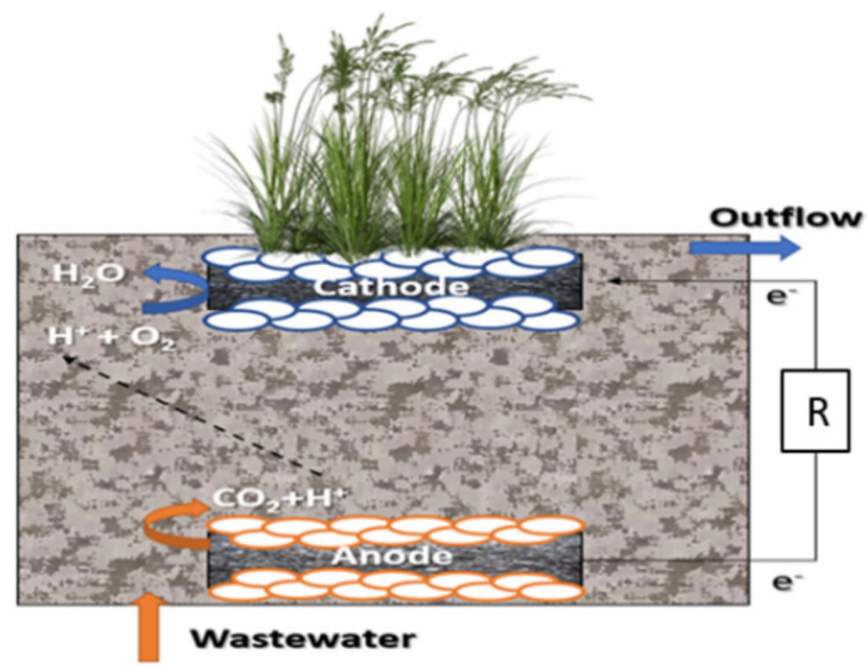

Figure 1. Schematic of constructed wetland MFC (CW-MFC) setup (R: Resistance).

Aquatic plants transport oxygen required for aerobic respiration to the root zone and, hence, release oxygen as an electron acceptor. In particular, the position of the cathode of MFCs in constructed wetlands is of great importance to provide optimal system performance. A cathode in contact with the water surface will provide an oxygen-rich environment for the occurring reactions; however, plant evapotranspiration might affect water levels and decrease the MFC-component performance by limiting oxygen transfer to the cathode and increasing the overall internal resistance of the system. It was shown that energy production under high daily water level variations was $40 \%$ lower than that under steady water levels [61].

As previously mentioned, the integration of BES in CWs requires an adequate distance between electrodes (usually around $10-20 \mathrm{~cm}$ ), which increases internal ohmic resistance and reduces current generation [62]. Glass-wool separators were tested to minimize distance between the anode and cathode while reducing losses and increasing maximum power density by $70 \%$; however, such arrangements imply additional costs and construction and operational difficulties and could degrade the performance of the system under high organic loads, due to limited oxygen availability at the cathode [63]. The use of a bentonite layer separating the lower anaerobic anode from the upper aerobic cathode in horizontal flow systems was also adopted [64].

While successfully achieving organic matter degradation, power generation is lower at higher organic loads, a common occurrence reported elsewhere [65]. Oon et al. [66] 
demonstrated a laboratory-scale, upflow CW-MFC with multiple layers of anodic material (activated carbon) intermixed within the soil matrix, and an upper cathode layer (also activated carbon) in contact with the CW's vegetation root system, obtaining COD, nitrate, and ammonium removal efficiencies of 99,46 , and $96 \%$, respectively. Contrary to what is normally observed, the higher organic loading rate improved the system's performance in terms of voltage output and power density; in this case the maximum power density increased $155 \%$ when the organic loading was doubled [66]. This could have been due to the particular multi-layer system architecture affecting internal resistances.

It was also observed that when CW-MFC systems were fed with COD of about $50 \mathrm{mg} / \mathrm{L}$, it took some time to stabilize the system, with low yield of bioelectricity and low vegetation vitality. However, when the same systems were fed with a tenfold COD load, greater removal of organic matter was achieved, with improved biocompatibility between plants and organic matter [67].

A multifactor orthogonal experiment study investigating the influence of various factors on CW-MFC performance determined that HRT was the most important factor for pollutant removal in these systems, contributing over 50\% to COD, ammonium, and phosphorus removal, and over $45 \%$ to $\mathrm{N}$ removal; the fraction of granular graphite (carbon component) in the substrate media was only significant for $\mathrm{N}$ removal, while the dissolved oxygen (DO) concentration at the cathode was extremely significant for organics and $\mathrm{N}$ removal. External resistance was the most (90\%) influential factor for electricity output, and also extremely significant for COD and nitrogen removal. The study also showed that the optimal operating conditions for the different components (COD, $\left.\mathrm{NH}_{3}-\mathrm{N}, \mathrm{TN}, \mathrm{TP}\right)$ were quite different from each other [68].

CW-MFCs have been reported being particularly effective in the removal of recalcitrant pharmaceuticals and personal care products (PPCPs): CW-MFCs were reported being successful in the removal of sulfadiazine, carbamazepine, naproxen, and ibuprofen at short HRTs; the dominant removal mechanism was electro-adsorption [69]. In addition, sulfonamide antibiotic resistance genes (ARGs) were detected in the electrodes and effluent and were linked to the mass accumulation of PPCPs on the electrodes. The coupling of a CW-MFC with a biofilm electrode reactor (BER) was reported removing over $97 \%$ of sulfamethoxazole (initial concentration: $4 \mathrm{mg} / \mathrm{L}$ ), even at a $16 \mathrm{~h} \mathrm{HRT}$, while the removal in the sole BER was limited to 47\% [70]. CW-MFCs were tested even at high concentrations of PPCPs (10 mg/L of ibuprofen and bisphenol A): the bottom and anode layers removed most of the PPCPs and COD, while bisphenol A addition led to toxicity effects on bacteria, negatively affecting ammonia removal [71]. High removal percentages in the removal of PPCPs can be attributed to the presence of multiple degradation pathways due to BES integration that may increase the removal of recalcitrant contaminants, as reported in Cecconet et al. [72].

GHG emissions from CWs are a major drawback of the technology [73]; integration with MFCs can help in the mitigation and control of $\mathrm{CH}_{4}$ emissions as reported by Wang et al. [74]. The presence of a MFC dramatically reduced the emissions of $\mathrm{CH}_{4}$ and $\mathrm{N}_{2} \mathrm{O}$; however, the reductions in emissions were strongly dependent on seasonality, organic loading, external resistance, and COD/TN ratio. A 45\% reduction in $\mathrm{CH}_{4}$ emissions was reported in a CW-MFC planted with Cyperus alternifolius compared to an identical system planted with Typha orientalis; closed circuit CW-MFCs obtained lower emissions than CW-MFCs operated in open circuit conditions, suggesting that the MFC integration was beneficial to the mitigation of GHG emissions.

In addition, CW-BES have been proposed as in situ treatment for PFAS (per- and polyfluoroalkyl substances) removal from water due to the different removal mechanisms that the hybrid system could apply [75]; however, no experimental applications of CW-BES on PFAS removal have been reported so far.

Despite the variety of applications of the hybrid CW-BES technology, some issues still need to be properly addressed and solved to allow a successful scaling up of the technology. Huge internal resistance may hinder electron transfers and therefore limit the 
electrochemical aspect of CW-BES [63]; microbial communities in the CW may compete for organic matter oxidation and therefore for electrons with the EABs, limiting the amount of them that can be transferred to the cathode, and therefore negatively impacting cathode kinetics; heterotrophic microorganisms' growth around the cathode may also limit cathodic reactions [66]. In addition, the challenging environment in CW can lead to fouling processes on the electrodes in the medium-long term [76]. Another issue that has been highlighted is the shape, number, and positioning of the electrodes, in combination with substrate supply to the biofilm on the electrodes, usually provided by recirculation in bench-scale studies but rather difficult in full-scale CW-BES [77].

Some issues deserve more in-depth discussion: for example, the suitability of CWbased technology for cold climates, as climate could strongly limit their applicability; integration may increase the need for assistance and maintenance, therefore limiting its application [78].

\subsection{Hybrid Algae-MFC Systems}

The combination of algae and MFCs promises to be a favorable technological setup. Algae may function as efficient electron acceptors in cathodic photosynthetic reactions and electron donors at the anode in syntrophic interaction with MFC EABs, also contributing to global CO2 mitigation processes $[79,80]$. Microalgae application in biocathodes allows to avoid the use of expensive catalysts, such as platinum, that makes the process economically unfavorable, consequently mitigating costs [81] and decreasing the dependency on chemicals/buffer solutions [82]. Furthermore, MFCs alone demonstrate little ammonia and nitrogen removal without post-treatment processes or specific bio-cathode assistance. One of the highest observed $\mathrm{NH}_{4}-\mathrm{N}$ removals in air cathode MFCs was lower then $45 \%$ [83]; this was increased by $59 \%$ compared to standalone MFC by an innovative algal biofilm/MFC complemented by a bioactive oxygen consuming unit (ABOCU-MFC) with the purpose to reduce algae-produced $\mathrm{O} 2$ diffusion to the anode by constraining it inside the cathodic compartment [84]. Developments of different types of microalgae MFCs were recently discussed by Saratale et al. [85]. These systems will also function with minimal net energy input since the need for oxygen supply is avoided or minimized, being generated by algal photosynthesis. Integration of microalgae in an MFC anodic chamber, either in the form of dry biomass or directly grown, has proven to be efficient due to their excellent characteristics as a substrate, in terms of carbohydrates, lipids, and protein content [86]. Not all algal species, however, may be ideal for this purpose, due to their high cellulose and hemicellulose content, which would require pretreatment before EAB processing [87]. Another potential issue concerning the use of microalgae in an anodic chamber may be exposure to light, which would lead to oxygen production and partial inhibition of anaerobic EABs [88]. Only few studies have focused on microalgae as mediator-less electron producers and carriers. Xu et al. used Chlorella pyrenoidosa and proved it was compatible with MFC technology by producing, under optimized conditions, a power density up to $6030 \mathrm{~mW} / \mathrm{m}^{2}$ [89]. It was observed that in particular circumstances, photosynthetic cyanobacteria could function as bioanode catalysts inducing higher electrogenic activity without oxygen production [90]; however, single chamber or biocathodic application of microalgae led to more significant advantages than applications in anodic chambers.

The photosynthetic activity of microalgae for oxygen provision as TEA may lead to several economic advantages: no expensive chemicals or catalysts are required, and system complexity and energy input are significantly reduced, since oxygen is directly generated by algal photosynthesis; consequently, external supply is avoided or minimized. Yuan et al. [91] demonstrated that blue-green algae could be effective feed for bioelectricity generation in a single-chamber tubular MFC, achieving a maximum power density of $114 \mathrm{~mW} / \mathrm{m}^{2}$ at blue-green algae concentration of $1113 \mathrm{mgCOD} / \mathrm{L}$ and contextual good removal efficiencies of COD, total nitrogen, and ammonium [91]. Fu and co-workers operated an MFC containing Spirulina platensis under different conditions of light, spacing of the electrodes, $\mathrm{pH}$, temperature, and connection methods, achieving better performance 
in the dark configuration in terms of energy production [92]. Among the most interesting applications in this area is the Integrated Photo-Bioelectrochemical (IPB) system, proposed by Xiao et al. [93], involving a unique integration of MFC in an algal bioreactor. Recent studies indicated that the key limitations of IPB combination systems may be linked to the MFC component [94]. An integrated treatment system consisting of MFCs and a membrane photobioreactor achieved $92-97 \%$ COD removal and nearly $100 \%$ ammonia removal, with production of over $130 \mathrm{mg} / \mathrm{L}$ treated of algal biomass [95] that can be used to further produce valuable products such as biodiesel or other high-value bioproducts $[26,29,96]$. Wang et al. operated an algae-based microbial carbon capture cell (MCC) to mitigate $\mathrm{CO}_{2}$ emissions, reporting significant $\mathrm{CO}_{2}$ conversion ( $94 \pm 1 \%$ ) and good performance in terms of power production $\left(5.6 \mathrm{~W} \mathrm{~m}^{-3}\right)$ [97]. Bazdar et al. investigated the effect of light intensities and illumination regimes on simultaneous production of bioelectricity, biomass, and wastewater treatment in a chamber photosynthetic microalgae microbial fuel cell (PMMFC), demonstrating that light/dark regimes influence both the MFC performance and microalgae lifetime [98]. The possibility of enhancing nutrients removal through the use of algal biocathodes was also investigated [99], as well as the use of algae in microbial desalination cells (MDCs), achieving excellent salinity removal (up to 79\%) but lower power densities than in microalgae-free systems [100]. Figure 2 summarizes microalgae integration alternatives in BES.
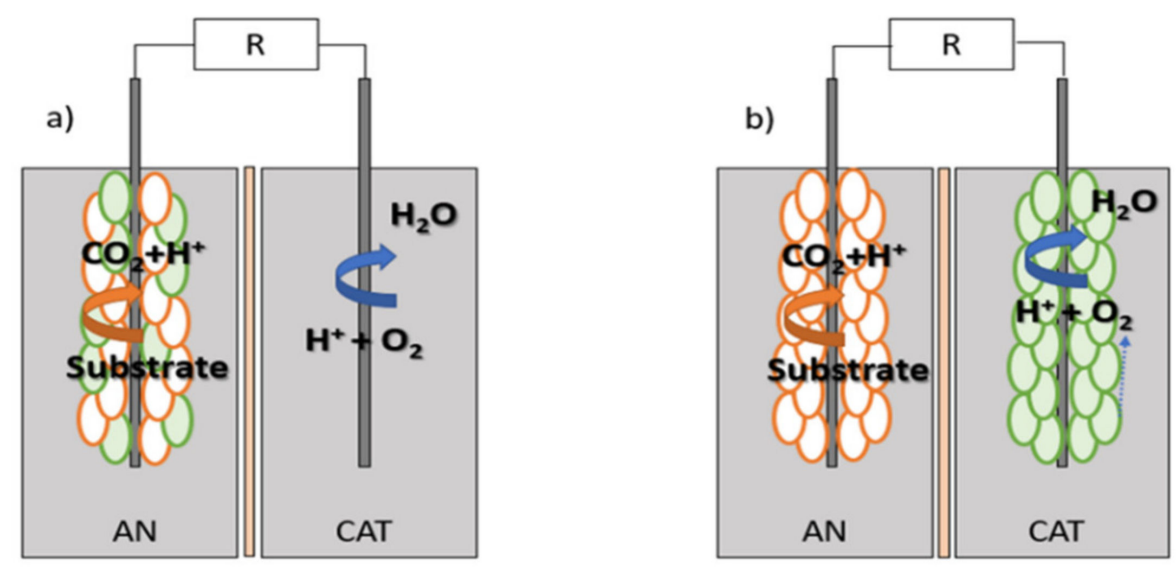

Legend:

$\mathrm{R}$ - Resistance

AN - Anode

CAT - Cathode

0 - Exoelectogenic biomass

- Microalgal biomass

Figure 2. Schematic of microalgae integration in BES: (a) Integrated Photo-Bioelectrochemical (IPB) system, (b) algal biocathode system configuration.

Despite efforts to increase the efficiency of these combined systems, a major issue inherent with MFC technology is the limitation of net energy production and recovery, linked to internal energy losses, which unfortunately does not seem to be sufficiently improved by the introduction of algae as oxygen providers. The presence of microalgae inside BES reactors in fact may increase the phenomenon of membrane fouling and, consequently, cause variations in the internal resistance of the systems, affecting overall electrical production [94]. Many other factors can alter the overall performance of the combined system: light/dark cycles will influence $\mathrm{O}_{2}$ production, growth rate, and algal stress of these processes; consequently, they may influence both bioelectricity production and possible recovery products from effluents, affecting the global energy and economic balance of the system [101]. If natural or simulated sunlight is not used during nighttime, oxygen is consumed by the microalgae's dark metabolism, leading to a decrease in the terminal electron acceptor's abundance in the reactor and affecting the electricity production profile [102].

Table 2 summarizes reported experiences in hybrid MFC-microalgae integrated systems. Despite the focus of most studies on bioelectricity production and nutrient removal by combined systems, a non-negligible advantage of microalgae integration is the possibil- 
ity of recovering algal-containing effluent, converting it into valuable products through algal biorefinery [103], increasing the global energy and economic balance of hybrid process, and forwarding their sustainability and appeal [26].

Table 2. Summary of previous experiences in hybrid MFC-microalgae integrated systems.

\begin{tabular}{|c|c|c|c|c|c|c|}
\hline Substrate & Microalgae Species & Configuration & CE (\%) & $\eta \operatorname{COD}(\%)$ & $\begin{array}{l}\text { Power Density } \\
\left(\mathrm{W} \mathrm{m}^{-3}\right)\end{array}$ & Ref \\
\hline Domestic wastewater & Chlorella vulgaris & Two chambers & 72 & 5.47 & 3.1 & [98] \\
\hline Domestic wastewater & Chlorella vulgaris & Two chambers & N.A. & 44 & 19 & [104] \\
\hline Micro-algae & Chlorella vulgaris & Two chambers & 6.3 & 90 & 8.7 & [105] \\
\hline Domestic wastewater & Chlorella vulgaris & Two chambers & 85 & N.A. & 5.6 & [97] \\
\hline Acetate & Mixed culture & Two chambers & N.A. & 90 & 8.7 & [93] \\
\hline Glucose & Chlorella vulgaris & Three chambers & N.A. & 65.6 & 0.15 & [106] \\
\hline Dairy wastewater & Mixed culture (Chlorella) & Two chambers & 9 & 98.1 & $1.9 \pm 0.5$ & [94] \\
\hline
\end{tabular}

\section{Microalgae-CW: Best of Both Worlds}

In the last decade, integration of CWs and microalgae-based processes has been proposed to increase the performances of both technologies.

The integration may happen by sequential treatment, in which the wastewater flows subsequently through different stages of the hybrid process. A pilot scale CW-microalgal system was developed by Bouali et al. [107], consisting of a duckweed CW followed by a microalgal pond. At 3 days of hydraulic retention time (HRT) the system was able to remove $\mathrm{COD}(67.5 \%), \mathrm{BOD}(70.6 \%)$, and $\mathrm{N}-\mathrm{NH}_{3}(65.9 \%)$ with no hydraulic failures. TP removal was strictly linked to algal growth, while total and fecal coliforms were only partially removed $(68.5 \%$ and $47.16 \%)$. The quality of the treated wastewater was compliant with Tunisian regulations for wastewater reuse in agriculture. Silveira et al. [108] presented an integrated system combining microalgae and a vertical flow $\mathrm{CW}$ for the treatment of urban wastewater; the system was composed of the sequential application of microalgae and $\mathrm{CW}$, and was able to remove the totality of $\mathrm{N}-\mathrm{NH}_{3}$ and $57 \%$ of influent $\mathrm{BOD}$, in addition to eliminating ecotoxicity and genotoxicity of the raw wastewater. A successive version of the system was compared against a UASB-based WWTP located in a university campus, and better results were obtained in COD, BOD, and ammonia removal, completely removing genotoxicity and mutagenicity and significantly reducing cytotoxicity [109]. An algal turf scrubber combined with a downflow $\mathrm{CW}$ was proposed for treatment of wastewater generated in a university campus [110]. The system operated at HRT of 21 days, and was able to almost completely remove coliforms and reduce the nutrient concentration below the limits imposed by Brazilian standards for wastewater reuse in garden and landscaping; $\mathrm{N}$ removal was attributed mainly to the algal stage.

In addition to sequential systems, microalgae can assist $\mathrm{CW}$ processes by enhancing their performances via integration in the $\mathrm{CW}$ setup. Algae were integrated into CWs to increase dissolved oxygen and consequently improve $\mathrm{CW}$ contaminant removal performances [111]. A comparison with an algae-free control reactor showed that the integrated system improved TN, TP, and COD removal by $30.6 \%, 21.2 \%$, and $20.2 \%$, respectively; the system was operated at low water temperatures $\left(2-10{ }^{\circ} \mathrm{C}\right)$, indicating good performance even in harsh climatic conditions. The use of microalgal dried biomass to sustain denitrification in CWs was explored by Zhong et al. [112], showing that the addition improved the nitrate removal efficiency by $27.9 \%$ and the $\mathrm{TN}$ removal efficiency by $17.7 \%$ compared to the control CW without addition.

\section{Full-Scale Applications of Hybrid Nature-Based Systems}

A further development of the CW-MFC scheme is the Microbial Electrochemicalbased Constructed Wetland (iMETland), which is, to the best knowledge of the authors, the sole full-scale application of the CW-BES concept [113]. Units were placed in Spain, Denmark, and Argentina. In a METland system, electrons are transferred to an electro- 
conductive biofilter (e.g., coke) that connects anoxic and oxic zones, acting as an unlimited acceptor to maximize substrate consumption. Limited availability of electron acceptors would leave free electrons for methane production, slowing down bacterial metabolism in anaerobic conditions.

The original setup of the METland was similar to a snorkel, which is a short-circuited MFC, in which kinetics are at their possible maximum [114]. Different materials have been tested, such as electroconductive coke [115] or biochar obtained from the pyrolysis of woody materials [116]; in addition, METland was effective in both aerated and non aerated mode, allowing different operating conditions and creating a mixed redox environment particularly adapted to Geobacter [117]. In the latest iteration of the system, METland reached its full scale and was able to treat $25 \mathrm{~m}^{3}$ of influent per day [118], obtaining excellent results in the removal of recalcitrant pharmaceuticals [119].

Despite the promising examples reported by recent literature, most of the hybrid systems tested so far were built at laboratory scale. The challenges for successful scaling up of this technology and achieving its practical implementation at real-scale are similar to those of traditional BESs for wastewater treatment applications. These limitations resulting in low achieved power density and coulombic efficiency include activation overpotentials, internal (ohmic) resistance, kinetic and diffusion resistance [120], microbial competition among EABs and methanogen bacteria for substrates [121-124], and cathode deterioration over time. Material (membranes, electrodes) limitations are also among the factors that heavily influence the performance of these systems [125].

Although most authors indicate their investigation priority as enhancing the power generation of MFCs, other advantages of these systems should be considered, as the observed energy yields so far are not suitable for use in power intensive applications. For example, Corbella et al. [126] reported a maximum power density generated by a small-size field-tested CW-MFC of $36 \mathrm{~mW} / \mathrm{m}^{2}$. This corresponds to a power production of $360 \mathrm{~W} / \mathrm{ha}$, which may be probably used for local, small applications, but hardly for anything more (by comparison, a hectare of solar panels produces about 10 times more power). Rather, exploitation of the properties of bioelectrochemical systems should be primarily addressed, with existing technology, to enhance the possibilities of onsite bioremediation by hybrid systems, such as the mentioned system footprint reduction, but also the inclusion of emerging contaminants as bioremediation targets. It is known that by controlling the operating conditions of BES systems, maximization of the contaminant degradation performance could be obtained, even for contaminants that normally would not undergo satisfactory degradation in natural systems [50,127-129].

Constructed wetlands can generally provide 1-2 log reduction for most pathogen indicator species, if appropriate contact time is emphasized in their design. Observed bacterial removal up to 5 log was observed, while protozoan (Cryptosporidium oocysts and Giardia cysts) removal of 0.4 to $1.7 \log$ was observed in FWS systems, and up to $3 \log$ in HSSF systems. Generally, little is known about the ability of CWs to remove disease-causing viruses from wastewater. Adsorption onto vegetation surfaces was indicated as the primary mechanism of virus removal [130], but few quantitative assessments could be found, mainly because detection and enumeration of human viruses in wastewaters is a process requiring considerable time and specialized equipment. A study by Gersberg et al. showed that removal efficiency for indicators of viral pollution was similar to that of bacteria (99 to 99.9\%) [131]. The recent appearance of SARS-CoV-2 coronavirus in water and wastewater was reported in several parts of the world; however, most coronaviruses are sensitive to temperature and are rapidly inactivated in the water environment at ambient temperature. To date, no published study on survivability of SARS-CoV-2 in water or wastewater is available; however, evaluation of the resistance of SARS-CoV-1 in different water matrices at $4{ }^{\circ} \mathrm{C}$ and $20^{\circ} \mathrm{C}$ showed that this organism survived for at most 2 days in dechlorinated tap water, hospital wastewater, and domestic sewage at $20^{\circ} \mathrm{C}$ [132]. This evidence suggests that, although CWs cannot be considered a particularly critical health concern, if used as a standalone system they cannot reliably meet microbiological effluent standards. 
The fate of pathogenic bacteria was investigated in continuously operating MFC systems by Ieropoulos et al., showing that the enteric pathogen Salmonella enterica's observed count reduction could reach $4 \log$ under closed-circuit conditions. This indicated the bactericidal properties of a well-performing anode, dependent on power performance and oxidation-reduction potential [133]. Observing the reduction of virulent genes in MFC residential metagenomes, it was suggested that MFC technology could become an efficient approach to the disinfection of hospital wastewaters [134]. Although the specific aspect of hybrid systems performance on pathogens inactivation has not been specifically studied, the limited evidence available so far is encouraging in this sense.

\section{Conclusions}

Hybrid nature-based systems for sustainable, decentralized sanitation and wastewater reuse are the subject on ongoing, continuous investigation. A combination of bioelectrochemical and nature-based technologies has shown the capability to enhance the performance of standalone traditional natural systems, such as constructed wetlands or microalgae-based systems. Many current studies address these system components and architecture, aimed at improving the bioelectrochemical performance of the technology and its use for removal of specific emerging pollutants (e.g., pesticides, pharmaceutical and personal care products, heavy metals and dyes), and improve their practical applicability. To enhance system performance, the main factors to be considered are the electrode materials, type of separators, operating microbiodome, and architecture. Electrode location affects the availability of oxygen at the cathode, and a better understanding of phenomena occurring in the rhizosphere is needed. The main challenges to implement in hybrid systems at full scale are long-term operation performance, i.e., maintaining vegetation vitality and preventing electrode materials from fouling and/or deteriorating, and optimization of operating conditions (i.e., organic loading, physicochemical and environmental parameters). Given the, so far, limited results achieved in energy harvesting from bioelectrochemical systems due to technological limitations, a more sustainable approach could consist in the maximization of the performance of natural systems, in terms of treatment efficiency and decreased footprint requirements, through their integration.

Author Contributions: Conceptualization, A.G.C., S.B. and D.C.; investigation, S.B. and D.C.; resources, A.G.C.; writing A.G.C., S.B. and D.C.; writing-final editing, A.G.C. All authors have read and agreed to the published version of the manuscript.

Funding: This research received no external funding.

Institutional Review Board Statement: Not applicable.

Informed Consent Statement: Not applicable.

Data Availability Statement: Not applicable.

Conflicts of Interest: The authors declare no conflict of interest.

\section{References}

1. Capodaglio, A.G. Integrated, Decentralized Wastewater Management for Resource Recovery in Rural and Peri-Urban Areas. Resources 2017, 6, 22. [CrossRef]

2. UNDP Millennium Development Goals Website 2020. Available online: http://www.undp.org/content/undp/en/home/ sustainable-development-goals.html (accessed on 16 June 2020).

3. Capodaglio, A.G.; Olsson, G. Energy issues in sustainable urban wastewater management: Use, demand reduction and recovery in the urban water cycle. Sustainability 2020, 12, 266. [CrossRef]

4. Parkinson, J.; Tayler, K. Decentralized wastewater management in peri-urban areas in low-income countries. Environ. Urban 2003, 15, 75-90. [CrossRef]

5. Capodaglio, A.G.; Ghilardi, P.; Boguniewicz-Zablocka, J. New paradigms in urban water management for conservation and sustainability. Water Pract. Technol. 2016, 11, 176-186. [CrossRef]

6. Libralato, G.; Volpi Ghirardini, A.; Avezzù, F. To centralise or to decentralise: An overview of the most recent trends in wastewater treatment management. J. Environ. Manag. 2011, 94, 61-68. [CrossRef] 
7. Chen, R.; Wang, X.C. Cost-Benefit evaluation of a decentralized water system for wastewater reuse and environmental protection. Water Sci. Technol. 2009, 59, 1515-1522. [CrossRef] [PubMed]

8. Capodaglio, A.G. Fit-for-purpose urban wastewater reuse: Analysis of issues and available technologies for sustainable multiple barrier approaches. Crit. Rev. Environ. Sci. Technol. 2020, 1-48. [CrossRef]

9. Opher, T.; Friedler, E. Comparative LCA of decentralized wastewater treatment alternatives for non-potable urban reuse. J. Environ. Manag. 2016, 182, 464-476. [CrossRef] [PubMed]

10. United States Environmental Protection Agency (US EPA). Response to Congress on Use of Decentralized Wastewater Treatment Systems; EPA-832-R-97-001b; US EPA Office of Water: Washington, DC, USA, 1997.

11. United States National Research Council. Water Reuse: Potential for Expanding the Nation's Water Supply through Reuse of Municipal Wastewater; National Academies Press: Washington, DC, USA, 2012.

12. Capodaglio, A.G. Taking the water out of "wastewater": An ineluctable oxymoron for urban water cycle sustainability. Water Environ. Res. 2020, 92, 2030-2040. [CrossRef]

13. Cecconet, D.; Bolognesi, S.; Piacentini, L.; Callegari, A.; Capodaglio, A.G. Bioelectrochemical greywater treatment for non-potable reuse and energy recovery. Water 2021, 13, 295. [CrossRef]

14. Istenic, D.; Bodík, I.; Bulc, T. Status of decentralised wastewater treatment systems and barriers for implementation of nature-based systems in central and eastern Europe. Environ. Sci. Pollut. Res. 2015, 22, 12879-12884. [CrossRef] [PubMed]

15. Masi, F.; Caffaz, S.; Ghrabi, A. Multi-stage constructed wetland systems for municipal wastewater treatment. Water Sci. Technol. 2013, 67, 1590-1598. [CrossRef]

16. He, Y.; Wang, Y.; Song, X. High-effective denitrification of low C/N wastewater by combined constructed wetland and biofilmelectrode reactor (CW-BER). Bioresour. Technol. 2016, 203, 245-251. [CrossRef]

17. Fink, D.F.; Mitsch, B.J. Seasonal and storm event nutrient removal by a created wetland in an agricultural watershed. Ecol. Eng. 2004, 23, 313-325. [CrossRef]

18. Brix, H. Wastewater treatment in constructed wetlands: System design, removal processes, and treatment performance. In Constucted Wetlands for Water Quality Improvement; Moshiri, G.A., Ed.; Lewis Publishers: Boca Raton, FL, USA, 1993 ; pp. 9-22.

19. Baptista, J.D.C.; Donnelly, T.; Rayne, D.; Davenport, R.J. Microbial mechanisms of carbon removal in subsurface flow wetlands. Water Sci. Technol. 2003, 48, 127-134. [CrossRef] [PubMed]

20. IRIDRA. Nature-Based Solutions-Sustainable Water Management. Available online: http:/ /www.iridra.eu/en/fitodepurazioneen.html (accessed on 15 May 2020).

21. Wu, H.; Zhang, J.; Guo, W.; Liang, S.; Fan, J. Secondary effluent purification by a large-scale multi-stage surface-flow constructed wetland: A case study in northern China. Bioresour. Technol. 2018, 249, 1092-1096. [CrossRef]

22. Li, X.; Li, Y.; Li, Y.; Wu, J. Enhanced nitrogen removal and quantitative analysis of removal mechanism in multistage surface flow constructed wetlands for the large-scale treatment of swine wastewater. J. Environ. Manag. 2019, 246, 575-582. [CrossRef]

23. Wu, S.; Kuschk, P.; Brix, H.; Vymazal, J.; Dong, R.A. Development of constructed wetlands in performance intensifications for wastewater treatment: A nitrogen and organic matter targeted review. Water Res. 2014, 57, 40-55. [CrossRef]

24. Henkanatte-Gedera, M.S.; Selvaratnam, T.; Caskan, N.; Nirmalakhandan, N.; Van Voorhies, W.; Lammers, P.J. Algal-based, single-step treatment of urban wastewaters. Bioresour. Technol. 2015, 189, 273-278. [CrossRef]

25. Li, K.; Liu, Q.; Fang, F.; Luo, R.; Lu, Q.; Zhou, W.; Huo, S.; Cheng, P.; Liu, J.; Addy, M.; et al. Microalgae-based wastewater treatment for nutrients recovery: A review. Bioresour. Technol. 2019, 291, 121934. [CrossRef]

26. Bolognesi, S.; Bernardi, G.; Callegari, A.; Dondi, D.; Capodaglio, A.G. Biochar production from sewage sludge and microalgae mixtures: Properties, sustainability and possible role in circular economy. Biomass Convers. Biorefinery 2021, 11, 289-299. [CrossRef]

27. Oswald, W.J.; Gotaas, H.B.; Golueke, C.G.; Kellen, W.R. Algae in waste treatment. Sew. Ind. Wastes 1957, 29 , 437-455.

28. Wu, W.; Chang, J.S. Integrated algal biorefineries from process systems engineering aspects: A review. Bioresour. Technol. 2019, 291, 121939. [CrossRef] [PubMed]

29. Callegari, A.; Bolognesi, S.; Cecconet, D.; Capodaglio, A.G. Production technologies, current role, and future prospects of biofuels feedstocks: A state-of-the-art review. Crit. Rev. Environ. Sci. Technol. 2020, 50, 384-436. [CrossRef]

30. Abdel-Raouf, N.; Al-Homaidan, A.A.; Ibraheem, I.B.M. Microalgae and wastewater treatment. Saudi J. Biol. Sci. 2012, 19, 257-275. [CrossRef] [PubMed]

31. Terumi Arashiro, L.; Montero, N.; Ferrer, I.; Acién, F.G.; Gómez, C.; Garfí, M. Life cycle assessment of high rate algal ponds for wastewater treatment and resource recovery. Sci. Total Environ. 2018, 622-623, 1118-1130. [CrossRef] [PubMed]

32. Sutherland, D.L.; Howard-Williams, C.; Turnbull, M.H.; Broady, P.A.; Craggs, R.J. Seasonal variation in light utilisation, biomass production and nutrient removal by wastewater microalgae in a full-scale high-rate algal pond. J. Appl. Phycol. 2014, 26, 1317-1329. [CrossRef]

33. De Godos, I.; Arbiba, Z.; Lara, L.; Rogalla, F. Evaluation of High Rate Algae Ponds for treatment of anaerobically digested wastewater: Effect of $\mathrm{CO}_{2}$ addition and modification of dilution rate. Bioresour. Technol. 2016, 220, 253-261. [CrossRef]

34. Sutherland, D.L.; Heubeck, S.; Park, J.; Turnbull, M.H.; Craggs, R.J. Seasonal performance of a full-scale wastewater treatment enhanced pond system. Water Res. 2018, 136, 150-159. [CrossRef]

35. El Hamouri, B.; Jellal, J.; Outabiht, H.; Nebri, B.; Khallayounea, K.; Benkerrouma, A.; Hajlia, A.; Firadi, R. The performance of a high-rate algal pond in the moroccan climate. Water Sci. Technol. 1995, 31, 67-74. [CrossRef] 
36. Lavrinovičs, A.; Juhna, T. Review on Challenges and Limitations for Algae-Based Wastewater Treatment. Constr. Sci. 2017, 20, 17-25. [CrossRef]

37. Wu, S.; Dong, X.; Chang, Y.; Carvalho, P.N.; Pang, C.; Chen, L.; Dong, R. Response of a tidal operated constructed wetland to sudden organic and ammonium loading changes in treating high strength artificial wastewater. Ecol. Eng. 2015, 82, 643-648. [CrossRef]

38. Foladori, P.; Ruaben, J.; Ortigara, A.R.C. Recirculation or artificial aeration in vertical flow constructed wetlands: A comparative study for treating high load wastewater. Bioresour. Technol. 2013, 149, 398-405. [CrossRef]

39. Songliu, L.; Hongying, H.; Yingxue, S.; Jia, Y. Effect of carbon source on the denitrification in constructed wetlands. J. Environ. Sci. 2009, 21, 1036-1043.

40. Wen, Y.; Xu, C.; Liu, G.; Chen, Y.; Zhou, Q. Enhanced nitrogen removal reliability and efficiency in integrated constructed wetland microcosms using zeolite. Front. Environ. Sci. Eng. 2012, 6, 140-147. [CrossRef]

41. Ilyas, H.; Masih, I. The performance of the intensified constructed wetlands for organic matter and nitrogen removal: A review. J. Environ. Manag. 2017, 198, 372-383. [CrossRef]

42. Schmidt, J.J.; Gagnon, G.A.; Jamieson, R.C. Microalgae growth and phosphorus uptake in wastewater under simulated cold region conditions. Ecol. Eng. 2016, 95, 588-593. [CrossRef]

43. Rozendal, R.A.; Hamelers, H.V.M.; Rabaey, K.; Keller, J.; Buisman, C.J.N. Towards practical implementation of bioelectrochemical wastewater treatment. Trends Biotechnol. 2008, 26, 450-459. [CrossRef]

44. Capodaglio, A.G.; Molognoni, D.; Dallago, E.; Liberale, A.; Cella, R.; Longoni, P.; Pantaleoni, L. Microbial fuel cells for direct electrical energy recovery from urban wastewaters. Sci. World J. 2013, 2013, 634738. [CrossRef]

45. Callegari, A.; Cecconet, D.; Molognoni, D.; Capodaglio, A.G. Sustainable processing of dairy wastewater: Long-term pilot application of a bio-electrochemical system. J. Clean. Prod. 2018, 189, 563-569. [CrossRef]

46. Kelly, P.T.; He, Z. Nutrients removal and recovery in bioelectrochemical systems: A review. Bioresour. Technol. 2014, 153, 351-360. [CrossRef]

47. Cecconet, D.; Bolognesi, S.; Callegari, A.; Capodaglio, A.G. Controlled sequential biocathodic denitrification for contaminated groundwater bioremediation. Sci. Total Environ. 2019, 651, 3107-3116. [CrossRef] [PubMed]

48. Bolognesi, S.; Cecconet, D.; Callegari, A.; Capodaglio, A.G. Bioelectrochemical treatment of municipal solid waste landfill mature leachate and dairy wastewater as co-substrates. Environ. Sci. Pollut. Res. 2021, 28, 24639-24649. [CrossRef] [PubMed]

49. Cecconet, D.; Sabba, F.; Devecseri, M.; Callegari, A.; Capodaglio, A.G. In situ groundwater remediation with bioelectrochemical systems: A critical review and future perspectives. Environ. Int. 2020, 137, 105550. [CrossRef] [PubMed]

50. Cecconet, D.; Callegari, A.; Capodaglio, A.G. Bioelectrochemical systems for removal of selected metals and perchlorate from groundwater: A review. Energies 2018, 11, 2643. [CrossRef]

51. Logan, B.E.; Hamelers, B.; Rozendal, R.; Schröder, U.; Keller, J.; Freguia, S.; Aelterman, P.; Verstraete, W.; Rabaey, K. Microbial Fuel Cells: Methodology and Technology. Environ. Sci. Technol. 2006, 40, 5181-5192. [CrossRef]

52. Modin, O.; Aulenta, F. Three promising applications of microbial electrochemistry for the water sector. Environ. Sci. Water Res. Technol. 2017, 3, 391-402. [CrossRef]

53. Cecconet, D.; Zou, S.; Capodaglio, A.G.; He, Z. Evaluation of energy consumption of treating nitrate-contaminated groundwater by bioelectrochemical systems. Sci. Total Environ. 2018, 636, 881-890. [CrossRef] [PubMed]

54. Capodaglio, A.G.; Molognoni, D.; Puig, S.; Balaguer, M.D.; Colprim, J. Role of Operating Conditions on Energetic Pathways in a Microbial Fuel Cell. Energy Procedia 2015, 74, 728-735. [CrossRef]

55. Cecconet, D.; Bolognesi, S.; Molognoni, D.; Callegari, A.; Capodaglio, A.G. Influence of reactor's hydrodynamics on the performance of microbial fuel cells. J. Water Process. Eng. 2018, 26, 281-288. [CrossRef]

56. Cecconet, D.; Devecseri, M.; Callegari, A.; Capodaglio, A.G. Effects of process operating conditions on the autotrophic denitrification of nitrate-contaminated groundwater using bioelectrochemical systems. Sci. Total Environ. 2018, 613-614, 663-671. [CrossRef]

57. Zhang, Y.; Liu, M.; Zhou, M.; Yang, H.; Liang, L.; Gu, T. Microbial fuel cell hybrid systems for wastewater treatment and bioenergy production: Synergistic effects, mechanisms and challenges. Renew. Sustain. Energy Rev. 2019, 103, 13-29. [CrossRef]

58. Cristiani, P.; Franzetti, A.; Bestetti, G. Monitoring of electro-active biofilm in soil. Electrochim. Acta 2008, 54, 41-46. [CrossRef]

59. Yadav, A.K.; Srivastava, P.; Kumar, N.; Abbassi, R.; Kanta Mishra, B. Constructed Wetland-Microbial Fuel Cell: An Emerging Integrated Technology for Potential Industrial Wastewater Treatment and Bio-Electricity Generation. In Constructed Wetlands for Industrial Wastewater Treatment; Alexandros, S.I., Ed.; John Wiley \& Sons Ltd.: Hoboken, NJ, USA, 2018; pp. 493-510.

60. Guadarrama-Pérez, O.; Gutiérrez-Macías, T.; García-Sánchez, L.; Guadarrama-Pérez, V.H.; Estrada-Arriaga, E.B. Recent advances in constructed wetland-microbial fuel cells for simultaneous bioelectricity production and wastewater treatment: A review. Int. J. Energy Res. 2019, 43, 1-22. [CrossRef]

61. Corbella, C.; Garfí, M.; Puigagut, J. Long-term assessment of best cathode position to maximise microbial fuel cell performance in horizontal subsurface flow constructed wetlands. Sci. Total Environ. 2016, 563-564, 448-455. [CrossRef] [PubMed]

62. Srikanth, S.; Venkata Mohan, S. Influence of terminal electron acceptor availability to the anodic oxidation on the electrogenic activity of microbial fuel cell (MFC). Bioresour. Technol. 2012, 123, 480-487. [CrossRef]

63. Doherty, L.; Zhao, Y.; Zhao, X.; Hu, Y.; Hao, X.; Xu, L.; Liu, R. A review of a recently emerged technology: Constructed wetland-Microbial fuel cells. Water Res. 2015, 85, 38-45. [CrossRef] [PubMed] 
64. Villasenor, J.; Capilla, P.; Rodrigo, M.A.; Canizares, P.; Fernandez, F.J. Operation of a horizontal subsurface flow constructed wetland-microbial fuel cell treating wastewater under different organic loading rates. Water Res. 2013, 47, 6731-6738. [CrossRef]

65. Molognoni, D.; Chiarolla, S.; Cecconet, D.; Callegari, A.; Capodaglio, A.G. Industrial wastewater treatment with a bioelectrochemical process: Assessment of depuration efficiency and energy production. Water Sci. Technol. 2018, 77, 134-144. [CrossRef]

66. Oon, Y.L.; Ong, S.A.; Ho, L.N.; Wong, Y.S.; Dahalan, F.A.; Oon, Y.S.; Lehl, H.K.; Thung, W.E. Synergistic effect of up-flow constructed wetland and microbial fuel cell for simultaneous wastewater treatment and energy recovery. Bioresour. Technol. 2016, 203, 190-197. [CrossRef]

67. Regmi, R.; Nitisoravut, R.; Charoenroongtavee, S.; Yimkhaophong, W.; Phanthurat, O. Earthen pot-plant microbial fuel cell powered by vetiver for bioelectricity production and wastewater treatment. Clean Soil Air Water 2018, 46, 1700193. [CrossRef]

68. Wang, X.; Tian, A.; Liu, H.; Zhao, X.; Peng, S. Optimizing the performance of organics and nutrient removal in constructed wetland-microbial fuel cell systems. Sci. Total Environ. 2019, 653, 860-871. [CrossRef]

69. Li, H.; Cai, Y.; Gu, Z.; Yang, Y.L.; Zhang, S.; Yang, X.L.; Song, H.L. Accumulation of sulfonamide resistance genes and bacterial community function prediction in microbial fuel cell-constructed wetland treating pharmaceutical wastewater. Chemosphere 2020, 248, 126014. [CrossRef] [PubMed]

70. Li, H.; Song, H.L.; Yang, X.L.; Zhang, S.; Yang, Y.L.; Zhang, L.M.; Xu, H.; Wang, Y.W. A continuous flow MFC-CW coupled with a biofilm electrode reactor to simultaneously attenuate sulfamethoxazole and its corresponding resistance genes. Sci. Total Environ. 2018, 637-638, 295-305. [CrossRef] [PubMed]

71. Li, H.; Zhang, S.; Yang, X.L.; Yang, Y.L.; Xu, H.; Li, X.N.; Song, H.L. Enhanced degradation of bisphenol A and ibuprofen by an up-flow microbial fuel cell-coupled constructed wetland and analysis of bacterial community structure. Chemosphere 2019, 217, 599-608. [CrossRef] [PubMed]

72. Cecconet, D.; Molognoni, D.; Callegari, A.; Capodaglio, A.G. Biological combination processes for efficient removal of pharmaceutically active compounds from wastewater: A review and future perspectives. J. Environ. Chem. Eng. 2017, 5, 3590-3603. [CrossRef]

73. Mander, Ü.; Dotro, G.; Ebie, Y.; Towprayoon, S.; Chiemchaisri, C.; Nogueira, S.F.; Jamsranjav, B.; Kasak, K.; Truu, J.; Tournebize, J.; et al. Greenhouse gas emission in constructed wetlands for wastewater treatment: A review. Ecol. Eng. 2014, 66, 19-35. [CrossRef]

74. Wang, X.; Tian, Y.; Liu, H.; Zhao, X.; Peng, S. The influence of incorporating microbial fuel cells on greenhouse gas emissions from constructed wetlands. Sci. Total Environ. 2019, 656, 270-279. [CrossRef]

75. Ji, B.; Kang, P.; Wei, T.; Zhao, Y. Challenges of aqueous per- and polyfluoroalkyl substances (PFASs) and their foreseeable removal strategies. Chemosphere 2020, 250, 126316. [CrossRef]

76. Xu, L.; Zhao, Y.; Wang, T.; Liu, R.; Gao, F. Energy capture and nutrients removal enhancement through a stacked constructed wetland incorporated with microbial fuel cell. Water Sci. Technol. 2017, 76, 28-34. [CrossRef]

77. Wang, Y.; Zhou, J.; Shi, S.; Zhou, J.; He, X.; He, L. Hydraulic flow direction alters nutrients removal performance and microbial mechanisms in electrolysis-assisted constructed wetlands. Bioresour. Technol. 2021, 325, 124692. [CrossRef] [PubMed]

78. Wu, S.; Lyu, T.; Zhao, Y.; Vymazal, J.; Arias, C.A.; Brix, H. Rethinking Intensification of Constructed Wetlands as a Green Eco-Technology for Wastewater Treatment. Environ. Sci. Technol. 2018, 52, 1693-1694. [CrossRef] [PubMed]

79. Wu, X.Y.; Song, T.S.; Zhu, X.J.; Wei, P.; Zhou, C. Construction and operation of microbial fuel cell with Chlorella vulgaris biocathode for electricity generation. Appl. Biochem. Biotechnol. 2013, 171, 2082-2092. [CrossRef] [PubMed]

80. He, Z.; Kan, J.; Mansfeld, F.; Angenent, L.T.; Nealson, K.H. Self-sustained phototrophic microbial fuel cells based on the synergistic cooperation between photosynthetic microorganisms and heterotrophic bacteria. Environ. Sci. Technol. 2009, 43, 1648-1654. [CrossRef] [PubMed]

81. Xia, X.; Tokash, J.C.; Zhang, F.; Liang, P.; Huang, X.; Logan, B.E. Oxygen-Reducing Biocathodes Operating with Passive Oxygen Transfer in Microbial Fuel Cells. Environ. Sci. Technol. 2013, 47, 2085-2091. [CrossRef]

82. Sevda, S.; Garlapati, V.K.; Sharma, S.; Bhattacharya, S.; Mishra, S.; Sreekrishnan, T.R.; Pant, D. Microalgae at niches of bioelectrochemical systems: A new platform for sustainable energy production coupled industrial effluent treatment. Bioresour. Technol. Rep. 2019, 7, 100290. [CrossRef]

83. Puig, S.; Serra, M.; Coma, M.; Cabre, M.; Dolors Balaguer, M.; Colprim, J. Microbial fuel cell application in landfill leachate treatment. J. Hazard. Mater. 2011, 185, 763-767. [CrossRef] [PubMed]

84. Elmaadawy, K.; Hua, J.; Guoa, S.; Hou, H.; Xu, J.; Wang, D.; Liang, T.; Yang, J.; Liang, S.; Xiao, K.; et al. Enhanced treatment of landfill leachate with cathodic algal biofilm and oxygen-consuming unit in a hybrid microbial fuel cell system. Bioresour. Technol. 2020, 310, 123420. [CrossRef]

85. Saratale, R.G.; Kuppam, C.; Mudhoo, A.; Saratale, G.D.; Periyasamy, S.; Zhen, G.; Kook, L.; Bakonyi, P.; Nemestothy, N.; Kumar, G. Bioelectrochemical systems using microalgae e A concise research update. Chemosphere 2017, 177, 35-43. [CrossRef]

86. Liu, W.F.; Cheng, S.A. Microbial Fuel Cells for Energy Production from Wastewaters: The Way toward Practical Application. J. Zhejiang Univ. Sci. A 2014, 15, 841-861. [CrossRef]

87. Gouveia, L.; Carole, N.; Diogo, S.; Nobre, B.P.; Matos, C.T. Effect of Light on the Production of Bioelectricity and Added-Value Microalgae Biomass in a Photosynthetic Alga Microbial Fuel Cell. Bioresour. Technol. 2014, 154, 171-177. [CrossRef]

88. Elmekawy, A.; Hegab, H.M.; Vanbroekhoven, K.; Pant, D. Techno-Productive Potential of Photosynthetic Microbial Fuel Cells through Different Configurations. Renew. Sustain. Energy Rev. 2014, 39, 617-627. [CrossRef] 
89. Xu, C.; Poon, K.; Choi, M.M.F.; Wang, R. Using live algae at the anode of a microbial fuel cell to generate electricity. Environ. Sci. Pollut. Res. 2015, 22, 15621-15635. [CrossRef]

90. Mohan, V.S.; Srikanth, S.; Chiranjeevi, P.; Arora, S.; Chandra, R. Algal biocathode for in situ terminal electron acceptor (TEA) production: Synergetic association of bacteria-microalgae metabolism for the functioning of biofuel cell. Bioresour. Technol. 2014, 166, 566-574. [CrossRef]

91. Yuan, Y.; Chen, Q.; Zhou, S.; Zhuang, L.; Hu, P. Bioelectricity generation and microcystins removal in a blue-green algae powered microbial fuel cell. J. Hazard. Mater. 2011, 187, 591-595. [CrossRef]

92. Fu, C.C.; Hung, T.C.; Wu, W.T.; Wen, T.C.; Su, C.H. Current and voltage responses in instant photosynthetic microbial cells with Spirulina platensis. Biochem. Eng. J. 2010, 52, 175-180. [CrossRef]

93. Xiao, L.; Young, E.B.; Berges, J.A.; He, Z. Integrated Photo-Bioelectrochemical System for Contaminants Removal and Bioenergy Production. Environ. Sci. Technol. 2012, 46, 11459-11466. [CrossRef]

94. Bolognesi, S.; Cecconet, D.; Callegari, A.; Capodaglio, A.G. Combined microalgal photobioreactor/microbial fuel cell system: Performance analysis under different process conditions. Environ. Res. 2021, 192, 110263. [CrossRef]

95. Tse, H.T.; Luo, S.; Li, J.; He, Z. Coupling microbial fuel cells with a membrane photobioreactor for wastewater treatment and bioenergy production. Bioprocess. Biosyst. Eng. 2016, 39, 1703-1710. [CrossRef]

96. Capodaglio, A.G.; Callegari, A.; Dondi, D. Microwave-Induced Pyrolysis for Production of Sustainable Biodiesel from Waste Sludges. Waste Biomass Valorization 2016, 7, 703-709. [CrossRef]

97. Wang, X.; Feng, Y.; Liu, J.; Lee, H.; Li, C.; Li, N.; Ren, N. Sequestration of CO2 discharged from anode by algal cathode in microbial carbon capture cells (MCCs). Biosens. Bioelectron. 2010, 25, 2639-2643. [CrossRef]

98. Bazdar, E.; Roshandel, R.; Yaghmaei, S.; Mahdi, M. The effect of different light intensities and light/dark regimes on the performance of photosynthetic microalgae microbial fuel cell. Bioresour. Technol. 2018, 261, 350-360. [CrossRef] [PubMed]

99. Nguyen, H.T.H.; Min, B. Leachate treatment and electricity generation using an algae-cathode microbial fuel cell with continuous flow through the chambers in series. Sci. Total Environ. 2020, 723, 138054. [CrossRef]

100. Saba, B.; Christy, A.D.; Yu, Z.; Co, A.C.; Park, T. Simultaneous Power Generation and Desalination of Microbial Desalination Cells Using Nannochloropsis salina (Marine Algae) Versus Potassium Ferricyanide as Catholytes. Environ. Eng. Sci. 2017, 34, 185-196. [CrossRef]

101. León-Vaz, A.; León, R.; Díaz-Santos, E.; Vigara, J.; Raposo, S. Using agro-industrial wastes for mixotrophic growth and lipids production by the green microalga Chlorella sorokiniana. New Biotechnol. 2019, 51, 31-38. [CrossRef]

102. Ma, J.; Wang, Z.; Zhang, J.; Waite, T.D.; Wu, Z. Cost-effective Chlorella biomass production from dilute wastewater using a novel photosynthetic microbial fuel cell (PMFC). Water Res. 2017, 108, 356-364. [CrossRef]

103. Lakaniemi, A.M.; Tuovinen, O.H.; Puhakka, J.A. Anaerobic conversion of microalgal biomass to sustainable energy carriers-A review. Bioresour. Technol. 2013, 135, 222-231. [CrossRef] [PubMed]

104. Hou, Q.; Pei, H.; Hu, W.; Jiang, L.; Yu, Z. Mutual facilitations of food waste treatment, microbial fuel cell bioelectricity generation and Chlorella vulgaris lipid production. Bioresour. Technol. 2016, 203, 50-55. [CrossRef]

105. Cui, Y.; Rashid, N.; Hu, N.; Saif, M.; Rehman, U.; Han, J. Electricity generation and microalgae cultivation in microbial fuel cell using microalgae-enriched anode and bio-cathode. Energy Convers. Manag. 2014, 79, 674-680. [CrossRef]

106. Kokabian, B.; Gude, V.G. Sustainable photosynthetic biocathode in microbial desalination cells. Chem. Eng. J. 2015, 262, 958-965. [CrossRef]

107. Bouali, M.; Zrafi, I.; Mouna, F.; Bakhrouf, A. Pilot study of constructed wetlands for tertiary wastewater treatment using duckweed and immobilized microalgae. Afr. J. Microbiol. Res. 2012, 6, 6066-6074. [CrossRef]

108. Silveira, E.O.; Moura, D.; Rieger, A.; Machado, E.L.; Lutterbeck, C.A. Performance of an integrated system combining microalgae and vertical flow constructed wetlands for urban wastewater treatment. Environ. Sci. Pollut. Res. 2017, 24, 20469-20478. [CrossRef] [PubMed]

109. Silveira, E.O.; Lutterbeck, C.A.; Machado, Ê.L.; Rodrigues, L.R.; Rieger, A.; Beckenkamp, F.; Lobo, E.A. Biomonitoring of urban wastewaters treated by an integrated system combining microalgae and constructed wetlands. Sci. Total Environ. 2020, 705,135864 [CrossRef] [PubMed]

110. De Souza Celente, G.; Colares, G.S.; Machado, Ê.L.; Lobo, E.A. Algae turf scrubber and vertical constructed wetlands combined system for decentralized secondary wastewater treatment. Environ. Sci. Pollut. Res. 2019, 26, 9931-9937. [CrossRef] [PubMed]

111. Zhimiao, Z.; Xinshan, S.; Yanping, X.; Yufeng, Z.; Zhijie, G.; Fanda, L.; Yi, D.; Wei, W.; Tianling, Q. Influences of seasons, N/P ratios and chemical compounds on phosphorus removal performance in algal pond combined with constructed wetlands. Sci. Total Environ. 2016, 573, 906-914. [CrossRef]

112. Zhong, F.; Huang, S.; Wu, J.; Cheng, S.; Deng, Z. The use of microalgal biomass as a carbon source for nitrate removal in horizontal subsurface flow constructed wetlands. Ecol. Eng. 2019, 127, 263-267. [CrossRef]

113. Ramírez-Vargas, C.A.; Prado, A.; Arias, C.A.; Carvalho, P.N.; Esteve-Núñez, A.; Brix, H. Microbial Electrochemical Technologies for Wastewater Treatment: Principles and Evolution from Microbial Fuel Cells to Bioelectrochemical-Based Constructed Wetlands. Water 2018, 10, 1128. [CrossRef]

114. Hoareau, M.; Erable, B.; Bergel, A. Microbial electrochemical snorkels (MESs): A budding technology for multiple applications. A mini review. Electrochem. Commun. 2019, 104, 106473. [CrossRef] 
115. Aguirre-Sierra, A.; Bacchetti De Gregoris, T.; Berná, A.; Salas, J.J.; Aragón, C.; Esteve-Núñez, A. Microbial electrochemical systems outperform fixed-bed biofilters for cleaning-up urban wastewater. Environ. Sci. Water Res. Technol. 2016, 2, 4435-4448. [CrossRef]

116. Prado, A.; Berenguer, R.; Esteve-Núñez, A. Electroactive biochar outperforms highly conductive carbon materials for biodegrading pollutants by enhancing microbial extracellular electron transfer. Carbon N.Y. 2019, 146, 597-609. [CrossRef]

117. Aguirre-Sierra, A.; Baccheti, T.; Salas, J.; Deus, A.; Esteve-Núñez, A. A new concept in constructed wetlands: Assessment of aerobic electroconductive biofilters. Environ. Sci. Water Res. Technol. 2020, 6, 1312-1323. [CrossRef]

118. Wang, X.; Aulenta, F.; Puig, S.; Esteve-Núñez, A.; He, Y.; Mu, Y.; Rabaey, K. Microbial electrochemistry for bioremediation. Environ. Sci. Ecotechnol. 2020, 1, 100013. [CrossRef]

119. Pun, A.; Boltes, K.; Letón, P.; Esteve-Nuñez, A. Detoxification of wastewater containing pharmaceuticals using horizontal flow bioelectrochemical filter. Bioresour. Technol. Rep. 2019, 7, 100296. [CrossRef]

120. Teoh, T.P.; Ong, S.A.; Ho, L.G.; Wong, Y.S.; Oon, Y.L.; Oon, Y.S.; Tan, S.M.; Thung, W.E. Up-flow constructed wetland-microbial fuel cell: Influence of floating plant, aeration and circuit connection on wastewater treatment performance and bioelectricity generation. J. Water Process. Eng. 2020, 36, 101371. [CrossRef]

121. Aelterman, P.; Versichele, M.; Marzorati, M.; Boon, N.; Verstraete, W. Loading rate and external resistance control the electricity generation of microbial fuel cells with different three-dimensional anodes. Bioresour. Technol. 2008, 99, 8895-8902. [CrossRef]

122. He, Z.; Minteer, S.D.; Angenent, L.T. Electricity generation from artificial wastewater using an upflow microbial fuel cell. Environ. Sci. Technol. 2005, 39, 5262-5267. [CrossRef] [PubMed]

123. Liu, S.; Feng, X.; Li, X. Bioelectrochemical approach for control of methane emission from wetlands. Bioresour. Technol. 2017, 241, 812-820. [CrossRef] [PubMed]

124. Capodaglio, A.G.; Cecconet, D.; Molognoni, D. An integrated mathematical model of microbial fuel cell processes: Bioelectrochemical and microbiologic aspects. Processes 2017, 5, 73. [CrossRef]

125. Logan, B.E.; Wallack, M.J.; Kim, K.Y.; He, W.; Feng, Y.; Saikaly, P.E. Assessment of Microbial Fuel Cell Configurations and Power Densities. Environ. Sci. Technol. Lett. 2015, 2, 206-214. [CrossRef]

126. Corbella, C.; Guivernau, M.; Vinas, M.; Puigagut, J. Operational, design and microbial aspects related to power production with microbial fuel cells implemented in constructed wetlands. Water Res. 2015, 84, 232-242. [CrossRef] [PubMed]

127. Aulenta, F.; Tocca, L.; Verdini, R.; Reale, P.; Majone, M. Dechlorination of trichloroethene in a continuous-flow bioelectrochemical reactor: Effect of cathode potential on rate, selectivity, and electron transfer mechanisms. Environ. Sci. Technol. 2011, 45, 8444-8451. [CrossRef]

128. Fang, Z.; Song, H.; Yu, R.; Li, X. A microbial fuel cell-coupled constructed wetland promotes degradation of azo dye decolorization products. Ecol. Eng. 2016, 94, 455-463. [CrossRef]

129. Capodaglio, A.G.; Callegari, A.; Molognoni, D. Online monitoring of priority and dangerous pollutants in natural and urban waters: A state-of-the-art review. Manag. Environ. Qual. 2016, 27, 507-536. [CrossRef]

130. Arden, S.; Ma, X. Constructed wetlands for greywater recycle and reuse: A review. Sci. Total Environ. 2018, 630, 587-599. [CrossRef] [PubMed]

131. Gersberg, R.M.; Stephen, T.; Lyon, R.; Brenner, R.; Elkins, B.V. Fate of Viruses in Artificial Wetlands. Appl. Environ. Microbiol. 1987, 53, 731-736. [CrossRef]

132. Tran, H.N.; Le, G.T.; Nguyen, D.T.; Juang, R.S.; Rinklebe, J.; Bhatnagar, A.; Lima, E.C.; Iqbal, H.; Sarmah, A.K.; Chao, H.P. SARS-CoV-2 coronavirus in water and wastewater: A critical review about presence and concern. Environ. Res. 2021, 193, 110265. [CrossRef] [PubMed]

133. Ieropoulos, I.; Pasternak, G.; Greenman, J. Urine disinfection and in situ pathogen killing using a Microbial Fuel Cell cascade system. PLoS ONE 2017, 12, e0176475. [CrossRef]

134. Vasieva, O.; Sorokin, A.; Szydlowski, L.; Goryanin, I. Do Microbial Fuel Cells have Antipathogenic Properties? J. Comput. Sci. Syst. Biol. 2019, 12, 3. 